\title{
MIOCENE SCLERACTINIAN CORALS OF GAVDOS ISLAND, SOUTHERN GREECE: IMPLICATIONS FOR TECTONIC CONTROL AND SEA-LEVEL CHANGES
}

\author{
Drinia, H. ${ }^{1}$, Pomoni-Papaioannou, F. ${ }^{1}$, Tsaparas, N. ${ }^{1}$ \& Antonarakou, A. ${ }^{1}$ \\ ${ }^{1}$ University of Athens, Faculty of Geology and Geoenvironment, Department of Hist. Geology - Palaeontology, \\ 15784 Athens, Greece, cntrinia@geol.uoa.gr
}

\begin{abstract}
Low-diversity scleractinian patch reefs that have been developed, during Early to Middle Tortonian, in Gavdos island are studied, aiming in a better understanding of the time and space relationships of the reef development and the associated basin fill evolution. Gavdos island consists part of a tectonically active setting constituting the southernmost extension of the Hellenic arc (Eastern Mediterranean). A representative Tortonian section (Bo section), located in the northwest part of the island, which hosts a mass occurrence of hermatypic corals, is studied. Scleractinian samples were collected from the upper $12 \mathrm{~m}$ of the section, which is characterized by interchanges of marly limestone and compact marls.

The reefs are represented by the coral species Heliastraea oligophylla, Porites maicientensis, Thegioastraea roasendai and Porites collegniana. The microfacies analysis showed that the mediumto-thin-bedded carbonates of the limestone-marl alternations comprise patch reefs (boundstones-framestones, SMF 16, sensu Wilson, 1975, FZ 7-8, sensu Flügel 1982) consisted of screractinian corals. Corals are associated with corallinacean algae. Patch reefs are associated by bioclastic packstones-floatstones, characterized by benthic foraminifera, calcareous algae, spines of echinoids, gastropods and molluscs. Reefs are laterally associated by a bioclastic limestone rich in planktonic forams, associated by detrital material (fragments of quartz, feldspars, quartzites and cherts). The studied reeffacies have been dolomitized and cemented in the meteoric realm. In places pseudomorphs after evaporites have been observed, tending to occlude cavities resulted after dissolution. The depositional environment corresponds to a moderate to high-energy inner platform setting, experiencing open-ocean influences. The pattern of coralgal reef development during Miocene, in the tectonically controlled Gavdos island, represents a complex interaction of tectonic activity and global sea-level changes.
\end{abstract}

Key words: Tortonian reef, scleractinian corals, microfacies analysis, palaeoenvironment.

\section{Introduction}

As palaeoclimatology has become a central topic of carbonate sedimentology, palaeoecology is particularly significant for climate research because the carbonate secreting biotas are very sensitive archives of climate. In this context, the taxonomic composition and internal structure of corals and coralline algae provides a powerful tool for palaeoecological reconstructions. Furthermore, combined analysis of microfacies and coral features provides a useful tool for palaeoenvironmental studies. 


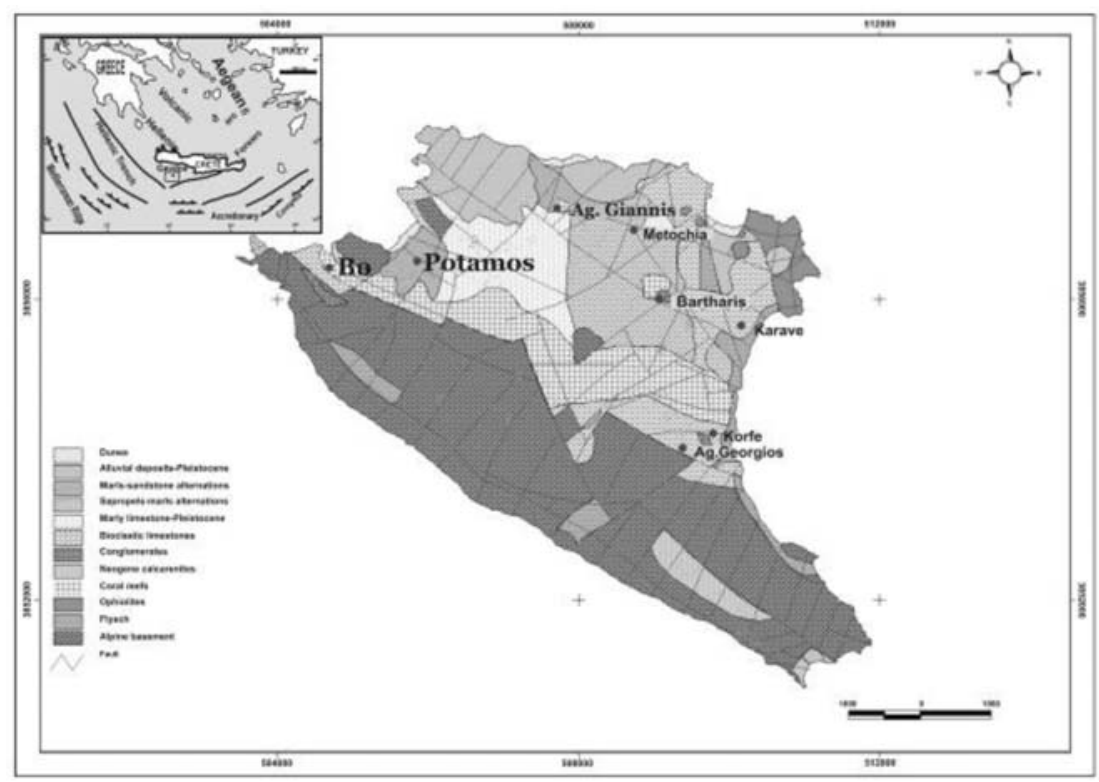

Fig. 1: Simplified geological map of Gavdos island (after Tsaparas, 2005, modified).

During the Oligocene and the Miocene, shallow-water carbonates of the Eastern Mediterranean region were rich in scleractinian corals thriving within various depositional settings, including different reef types. Their diversity patterns, although related to a complex interplay between a suite of environmental factors, are considered to be strongly controlled by climate variability and changes in sea-surface water temperature.

The aim of this paper is the documentation of the distribution of the scleractinian coral assemblages in Tortonian and the depositional environment recognition. Field observations revealing the lithofacies associations arrangement, are combined with detailed micropaleontological and microfacies analyses.

\section{Geological setting}

The island of Gavdos is located in the Eastern Mediterranean and constitutes the southernmost extension of the Hellenic arc (Fig. 1).

During the Serravallian, the island of Gavdos consisted of emerged sediments, of the Pre-Neogene basement. Field observations together with micropalaeontological analysis (Anastasakis et al. 1995) showed that at the end of Serravallian, the island was probably affected by drastic subsidence which resulted in the transformation of the central-west part of the island into a single shelf characterized by hemipelagic sedimentation. During the Early Tortonian, differentiated fault activity broke up this shelf into individual sub-basins forming separate palaeogeographic spaces (Tsaparas 2005).

Early Tortonian was characterized by the development of a WNW-ESE coral reef barrier which acted as a structural limit restricting water exchanges between these sub-basins (Fig. 2, Tsaparas and Dermitzakis 2005). Therefore, Bo shelf (NNW of Gavdos island), which is characterized by the presence of a rich scleractinian fauna (Tsaparas and Marcopoulou-Diakantoni 2005) indicates a 


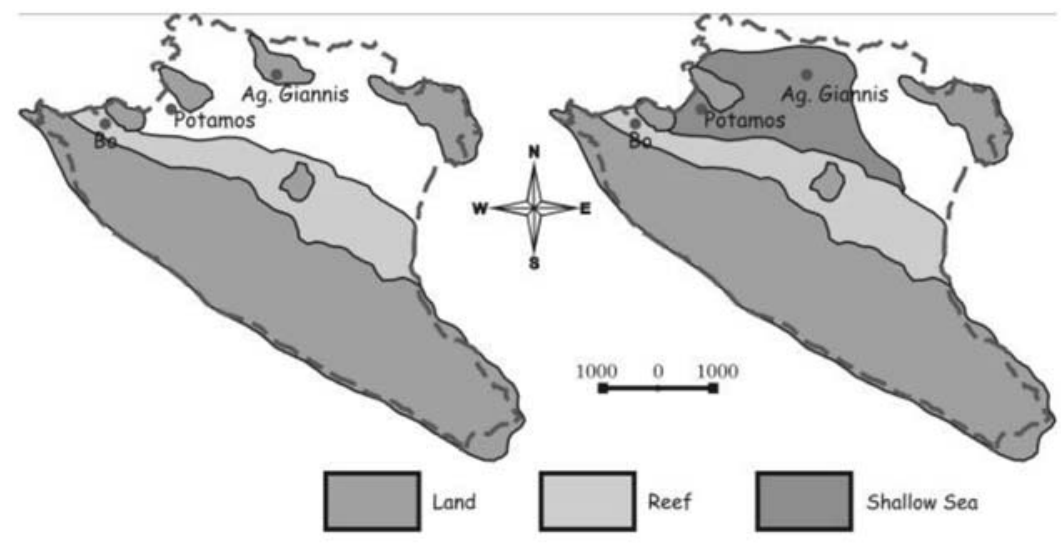

Fig. 2: Palaeogeographical reconstruction of Gavdos Island during Early and late Early Tortonian (after Tsaparas 2005 and Tsaparas and Dermitzakis 2005).
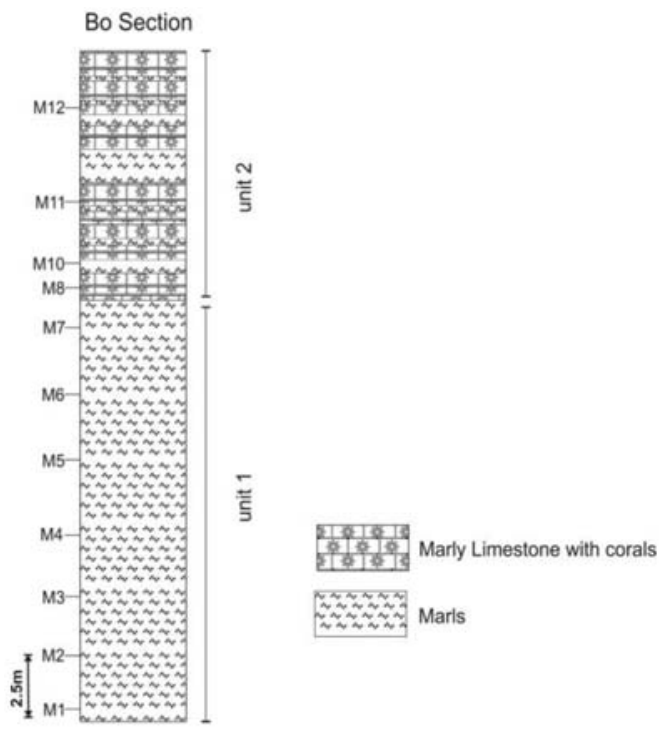

Fig. 3: Lithostratigraphical column of the studied section (after Tsaparas 2005).

warm and a rather oligotrophic environment whereas the time-equivalent Potamos shelf hosts species inhabiting brackish water lagoons or shelves (Drinia 2009).

This study is restricted in one representative Tortonian section (Bo section), located in the northwest part of the island, which hosts a mass occurrence of hermatypic corals. The section is $25 \mathrm{~m}$ thick and its sediments are arranged into two different types of lithofacies associations, constituting a shallowing-upward sequence (Fig. 3).

The basal part is composed of a marl succession. These marls are well bedded, variably lithified and consist almost entirely of carbonate with abundant foraminifera (Antonarakou et al. 2007, Drinia 2009). Approximately half way up the section, the dominantly fine-grained deposits change from blue marls to rhythmic bioclastic limestone-marl alternations. This transition takes place over a few 


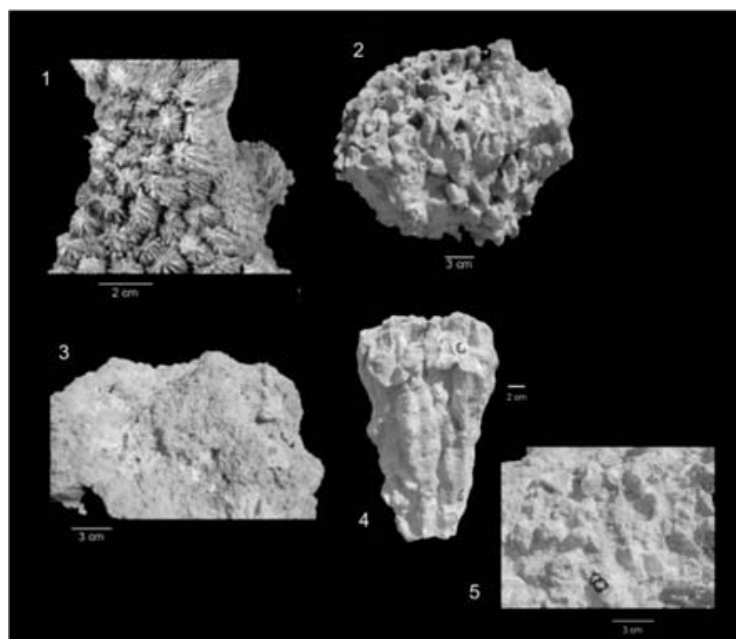

Fig. 4: 1. Thegioastraea roasendai (MICHELOTTI), 2. Porites collegniana (MICHELOTTI), 3. Heliastraea oligophylla (REUSS), 4, 5. Porites mancietensis CHEVALIER (photos originate from Tsaparas \& MarcopoulouDiakantoni 2005, 1=Table III,1, 2=Table II,5, 3=Table I,3, 4=Table II, 1, 5=Table II, 2).

tens of centimetres passing from bluish marl with abundant planktonic foraminifera to marl with macrofossils and then into hard bioclastic limestone. The marl succession in the studied section is $14 \mathrm{~m}$ thick and has been dated using planktonic foraminifera as being of early Late Miocene (early Tortonian) age, being characterized by the co-existence of the benthic foraminifera Uvigerina spp. and Cancris auricula which indicate a rather deep, mesotrophic to eutrophic environment (Drinia 2009). On the contrary, the upper part of the succession (12 to $25 \mathrm{~m}$ ) is dominated by a group of plano-convex benthic foraminiferal species which appear to have a low tolerance for salinity deviations. Scleractinian samples were collected from the upper $12 \mathrm{~m}$ of the record, which is characterized by interchanges of marly limestone and compact marls.

\section{Material and Methods}

A detailed microfacies analysis has been performed. Analysis of matrix and grains, textural features, fossil content, petrographic and energy index classification, facies zone, standard microfacies zone and model, formation, origin, correlation and interpretation criteria, as determined from thin sections study, is attempted (Dunham 1962, Folk 1962, Plumley et al. 1962, Selley 1970, Wilson 1975). The present study focuses on the study of the early and late diagenetic cement patterns. X-ray analysis was performed, as well.

\section{Results}

\subsection{Microfacies Analysis}

The microfacies analysis showed that the medium-to-thin-bedded carbonates of the limestone-marl alternations comprise patch reefs (boundstones-framestones, SMF 16, sensu Wilson 1975, FZ 7-8, sensu Flügel 1982) consisted of scleractinian corals.

A mass occurrence of hermatypic corals, with dominant Heliastraea oligophylla, Porites maicietensis, Thegioastraea roasendal and Porites collegniana (Fig. 4) characterize the studied carbon- 


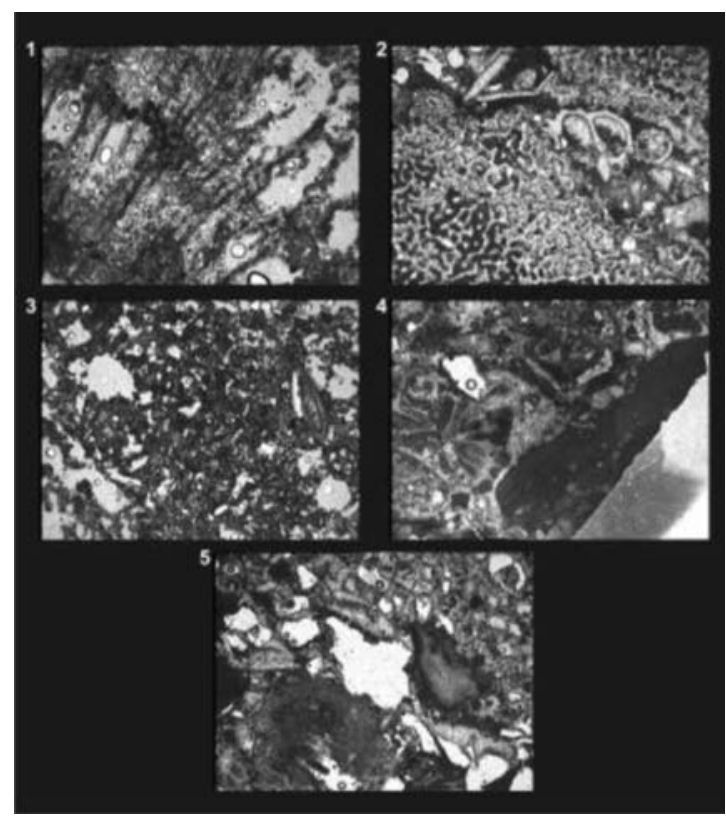

Fig. 5: 1. Patch reefs consisted of scleractinid corals (boundstones: framestones/ bafflestones, SMF 7, sensu Wilson, 1975, FZ 7-8, sensu Flügel 1982). Due to meteoric diagenesis intraskeletal porosity is reduced by cement growth (dog-teeth and blocky cement) (1,6X), 2. Boundstones consisted of scleractinid corals, associated by bioclastic packstones with spines of echinoids, gastropods and molluscs. Bioclasts are dissolved and filled by blocky calcite $(1,6 \mathrm{X}), 3$. Bioclastic limestone rich in planktonic forams, benthic foraminifera and detrital material (fragments of quartz, feldspars, quartzites and cherts) $(1,6 \mathrm{X}), 4$. Boundstone with corallinacae algae and bryozoans $(1,6 \mathrm{X}), 5$. Boundstones intensively affected by meteoric diagenesis. Intraskeletal porosity is reduced by cement growth (blocky cement) $(1,6 \mathrm{X})$.

ate interlayers representing laterally distributed reefal build-ups, indicative of highly variable environmental conditions, related to higher temperatures and salinities and sea-level change.

Corals are associated with corallinacean algae, which surround the corals. Bryozoans are neither abundant, nor diverse in the sampled coral facies. Most are encrusting and only some of them can be considered as accessory framework builders.

Patch reefs are associated by a coarse grained packstone-floatstone, characterized by spines of echinoids, calcareous algae, and fragments of corallinacean algae, gastropods and molluscs (Fig. 5). Reef facies is laterally associated by a wackestone-packstone with planktonic forams, in places rich in detrital material (fragments of quartz, feldspars, quartzites and cherts).

\subsection{Diagenesis}

The reef facies has undergone diagenesis in the meteoric realm (Fig. 5e), including dolomitization and dissolution of aragonite /high-Mg calcite that constituted the scleractinid corals, as well the bioclasts. Intraskeletal porosity is reduced by cement growth. The resulting pores have been filled firstly by a thin halo of dog-teeth cement, open spaces either remaining empty or filled by bladed and/or blocky cement. Meniscus cement occurs, as well. In places, spaces resulted after dissolution have been filled by cement reminding pseudomorphs after evaporites. Marine cement has not been detected. 


\subsection{Depositional Environment}

The depositional environment corresponds to a moderate to high-energy inner platform setting, possibly of ramp type (inner-mid ramp), experiencing open-ocean influences, in which patch reefs have been developed, forming a WNW-ESE coral reef barrier which acted as a structural limit restricting water exchanges between sub-basins.

\section{Discussion}

The low diversity of scleractinid corals in the studied reefs, together with the presence of high-tolerance species as Porites is characteristic of Mediterranean Miocene reefs, particularly in the middle to late Miocene (Chevalier 1961, Rouchy et al. 1986, Flecker et al. 1995) and suggests that the environment was under stress conditions.

The relatively sharp transition from the lower succession that consists entirely of deeper-water, lower energy, planktonic-foraminiferal rich marls, to shallow-water, high-energy reefs, implies that a major relative sea level fall took place.

According to Le Pichon and Angelier (1979), Meulenkamp and Hilgen (1986), extensional tectonics controlled the evolution of the southwestern part of the Aegean region along the Tortonian. Relative sea level fluctuations related to extensional tectonics could have been the main cause giving way to the sequential evolution. Tectonic pulses increases and created accommodation space drowning the coral patch-reefs and favoring marl sedimentation. Nevertheless, the general trend of the studied succession was shallowing upwards, with the shallowest facies in the upper part.

\section{Conclusions}

The study of the coral patch reefs from one Tortonian section of Gavdos island shed light on the palaeoenvironmental conditions, paying special attention to the palaeoecology of the corals. The main conclusions can be summarized as follows:

(a) Depositional structures, benthic organisms and the carbonate microfacies indicate restricted to open-marine, moderate energy inner platform setting.

(b) The low diversity of corals in these reefs, together with the presence of high tolerance species as Porites suggests that the environment was under stress conditions.

(c) The relatively sharp transition from the lower succession that consists almost entirely of deeperwater, lower energy, planktonic-foraminiferal rich marls, to shallow-water, high-energy reefs, implies that a relative sea level fall took place.

\section{Acknowledgements}

This study has been funded by the University of Athens, Research Projects KA 70/4/7612 and KA 70/4/8643. The authors are indebted to Prof. A. Marcopoulou-Diancantoni for help with determinations of corals.

\section{References}

Anastasakis, G.C., Dermitzakis, M.D., Triantaphyllou, M.V. 1995. Stratigraphic framework of the Gavdos island Neogene sediments, Newsletters on Stratigraphy 32, 1-15.

Antonarakou, A., Drinia, H., Tsaparas, N., Dermitzakis, M.D. 2007. Assessment of micropaleontological 
sedimentary parameters as proxies of surface water properties and paleoclimate, in Gavdos island, eastern Mediterranean, Geodiversitas 29, 379-399.

Chevalier, J.P. 1961. Récherches sur les Madréporaires et les formations récifales Miocene de la Méditerranée occidentale, Mém. Soc. Géol. Fr., 40/90.

Dunham, R.J. 1962. Classification of carbonate rocks according to depositinal texture. In: Hom, W.E. (ed.), Classification of Carbonate Rocks, AAPG, Mem. 1, 108-121.

Drinia, H. 2009. Foraminiferal biofacies and paleoenvironmental implications of the Early Tortonian deposits of Gavdos island (Eastern Mediterranean), Revue de micropaleontologie 52, 15-29.

Flecker, R., Robertson, A.H.F., Poisson, A., Müller, C. 1995. Facies and tectonic significance of two constrasting Miocene basins in south coastal Turkey, Terra Nova 7, 221-232.

Folk, R.L. 1962. Spectral subdivision of limestone types. In: Hom, W.E. (ed.), Classification of Carbonate Rocks, AAPG, Mem. 1, 62-84.

Flügel, E., 1982. Microfacies Analysis of Limestones. Springer-Verlag, 375 p,

Le Pichon, X., Angelier, J. 1979. The Hellenic Arc and Trench System: a key to the neotectonic evolution of the Eastern Mediterranean, Tectonophysics 60, 1-42.

Meulenkamp, J.E., Hilgen, F.J. 1986. Event stratigraphy, basin evolution and tectonics of the Hellenic and Calabro-Sicilian arcs, In: Wezel, F.C. (Ed), "The Origin of Arcs", Elsevier, Amsterdam, 327-350.

Plumley, W.J., Risley, G.A., Graves, R.W., Kaley, M.E. 1962. Energy index for limestone interpretation and classification, In: Hom, W.E. (ed.), Classification of Carbonate Rocks, AAPG, Mem. 1, 85-107.

Rouchy, J.-M., Saint Martin J.-P., Maurin A., Bernet-Rollande M.-C., 1986. Evolution and antagonism of coral and microbial communities in the Miocene in the western Mediterranean: biology and sedimentology, Bull. Cent. Rech. Expl. Prod. Elf-Aquitaine, 10, 333-348.

Selley, R.C. 1970. Ancient sedimentary environments, Science paperbacks 287.

Tsaparas N., 2005, Contribution to the history of sedimentation of the Upper Cenozoic marine formations in Gavdos Island. PhD Thesis, University of Athens.

Tsaparas, N., Marcopoulou-Diakantoni, A. 2005. Tortonian scleractinian corals from the Island of Gavdos, Revue de Paleobiologie 24, 629-637.

Tsaparas, N., Dermitzakis, M.D. 2005. Palaeogeographic evolution of the Neogene sediments of Gavdos island, $12^{\text {th }}$ Congress R.C.M.N.S., 6-11 September 2005, Vienna, Abstracts, 235-236.

Wilson J.L., 1975, Carbonate Facies in Geologic History. Springer-Verlag: 471 p., Berlin. 